\title{
TRAP AND SOIL MONOLITH SAMPLED EDAPHIC SPIDERS (ARACHNIDA: ARANEAE) IN Araucaria angustifolia FOREST
}

\author{
Dilmar Baretta ${ }^{1}$; Antonio Domingos Brescovit ${ }^{2}$; Irene Knysak ${ }^{2}$; Elke Jurandy Bran Nogueira \\ $\operatorname{Cardoso}^{3 *}$ \\ ${ }^{1}$ USP/ESALQ - Programa de Pós-Graduação em Solos e Nutrição de Plantas. \\ ${ }_{3}^{2}$ Instituto Butantan, Lab. de Artrópodes, Av. Vital Brasil, 1500 - 05503-900 - São Paulo, SP - Brasil. \\ ${ }^{3}$ USP/ESALQ - Depto. de Ciência do Solo, C.P. 9 - 13418-900 - Piracicaba, SP - Brasil. \\ *Corresponding author <ejbncard@esalq.usp.br>
}

ABSTRACT: Forests with Araucaria angustifolia (Bert.) O. Kuntze trees are endangered in Brazil, and information on the diversity of soil spider families associated to these environments is practically inexistent. The present study was set up to evaluate the abundance and diversity of soil spider families in natural and reforested Araucaria forests, impacted or not by fire, and to identify the most efficient method to collect these organisms. The study was conducted in four areas: native forest with predominance of Araucaria (NF); Araucaria reforestation (R); Araucaria reforestation submitted to an accidental fire (RF); and native grass pasture with native Araucaria and submitted to an intense accidental fire (NPF). Considering both sampling methods (Monolith and Pitfall traps), 20 spider families were identified. The pitfall trap method was more effective as it captured 19 out of the 20 recorded families, while the Monolith method extracted only ten spider families. Spider family abundance and Shannon's diversity index $(\mathrm{H})$ were affected by the employed collection method; the values for these attributes were always higher for the NF and lower for the NPF. Correspondence analysis (CA) showed a spatial separation among spider familiy assemblages from the different studied areas. It is suggested that changes in the abundance of soil spider families in Araucaria forests are mainly caused by recurrent human intervention over the last few years.

Key words: Atlantic Rainforest, spider fauna, spider diversity, bioindicators

\section{ARANHAS (ARACHNIDA: ARANEAE) EDÁFICAS AMOSTRADAS POR ARMADILHAS E MONÓLITOS DE SOLO EM FLORESTAS COM Araucaria angustifolia}

RESUMO: As florestas com Araucaria angustifolia (Bert.) O. Kuntze estão ameaçadas de extinção no Brasil, e são praticamente inexistentes as informações sobre a diversidade de famílias de aranhas de solo associadas nestes ambientes. O estudo teve o objetivo de avaliar, em florestas com araucária naturais e reflorestadas, impactadas ou não pela queima acidental, a abundância e diversidade de famílias de aranhas, além de identificar o método mais eficiente para coletar estes organismos. O estudo foi conduzido em quatro áreas: floresta nativa com predominância de araucária (NF); reflorestamento de araucária (R); reflorestamento de araucária submetido a incêndio acidental (RF); e pastagem natural com araucárias nativas e ocorrência de incêndio acidental (NPF). Considerando os dois métodos de amostragem (Monólito e armadilhas de solo), foram identificadas 20 famílias de aranhas associadas às áreas. O método das armadilhas de solo foi mais eficiente, capturando 19 das 20 famílias registradas, enquanto o do Monólito extraiu apenas dez destas famílias de aranhas. A abundância de famílias de aranhas e o índice de diversidade de Shannon $(\mathrm{H})$ foram afetados pelo método de coleta utilizado, sendo os valores destes atributos sempre superiores na NF e inferiores na NPF. A análise de correspondência (AC) demonstrou que existe separação espacial entre as áreas estudadas. Sugerese que as modificações na abundância de famílias de aranhas de solo sejam provocadas principalmente pelas intervenções antrópicas que as florestas de araucária vêm sofrendo nos últimos anos.

Palavras-chave: Floresta Atlântica, Araneofauna, diversidade de aranhas, bioindicadores 


\section{INTRODUCTION}

The accelerated process of fragmentation of the Atlantic Rainforest occurring in the State of São Paulo (Brazil), especially in the Subtropical Ombrophilous Forest (Araucaria forest) is reaching significant proportions, which could affect its biodiversity (Indicatti et al., 2005). Araucaria angustifolia (Bertoloni) Otto Kuntze (Araucariaceae) is an endangered tree species native to Brazil. Very little is known about the diversity of organisms associated to these peculiar ecosystems (Moreira et al., 2006).

The abundance of soil spider families in this forest may decrease significantly after anthropogenic intervention, thus affecting the population dynamics of plants and other edaphic organisms, and eventually compromising the natural regeneration of this forest ecosystem (Harris, 1984). The effects of fragmentation can be analyzed based on studies on the ecology of communities in remnants with different characteristics, by means of modifications in the structure and abundance of the edaphic fauna (Odum, 1983). However, to evaluate such impacts, the first step consists in performing an inventory of the fauna and flora of a given forest (Benati et al., 2005). The knowledge about the Atlantic Rainforest invertebrates is scant (Benati et al., 2005), and literature data concerning spider diversity in ecosystems containing Araucaria angustifolia trees, either natural or impacted by anthropogenic intervention in the State of São Paulo, are almost nonexistent.

Although spiders constitute a little-studied group in Brazil, they represent a significant part of the terrestrial arthropod diversity (Platnick, 2006), with approximately 39,500 species described to date, distributed among 108 families and 3,642 genera (Platnick, 2006). Recently, about 700 spider species were recorded for the State of São Paulo, distributed among 44 families (Candiani et al., 2005), but estimates point to more than 1,000 species (Brescovit, 1999). However, studies involving soil spiders have in- creased substantially in the past decades in Brazil and worldwide (Brescovit, 1999; Brennan et al., 2005; Rodrigues, 2005; Pinkus-Rendón et al., 2006; Platnick, 2006) due to an increasing interest in the biodiversity of organisms associated to forest ecosystems. Nevertheless sampling and extraction problems for these organisms still exist and need to be overcome (Brennan et al., 2005).

Most of the existing sampling methods under or overestimate the density and diversity of edaphic spiders in ecosystems (Brennan et al., 2005). The adoption of a single sampling method may not be effective to evaluate spider diversity in an area (Barreiros et al., 2005). When a more precise analysis of the spider diversity present in an Araucaria ecosystem is needed, for example, the adoption of more than one sampling method is recommended (Brennan et al., 2005). In this regard, the study's goal was to survey data on the abundance and diversity of soil spider families in natural and reforested Araucaria forest, impacted or not by fire, and to identify the most efficient method to collect organisms.

\section{MATERIAL AND METHODS}

This work was carried out Campos do Jordão, SP, Brazil, in four representative Araucaria angustifolia (Bert.) O. Ktze. forests, within the Campos do Jordão State Park, located $210 \mathrm{~km}$ away from the city of São Paulo. The soil in the four Araucaria forest areas is a clayey-textured Typic Hapludox (Table 1). Summer is the season with the most precipitation, and more than $240 \mathrm{~mm}$ of rainfall may occur in the month of February, while in September rainfall amounts to approximately $88 \mathrm{~mm}$; the mean temperature may vary from $17.5^{\circ} \mathrm{C}$ in February to $11.5^{\circ} \mathrm{C}$ in June. According to Köppen's classification, the climate in the region is defined as subtropical (upland), mesothermal, and humid $(\mathrm{Cfb})$.

Four Araucaria forests containing Araucaria trees were selected: a native, climax forest (220 $41^{\prime} 29^{\prime \prime}$

Table 1 - Soil chemical characteristics in natural forest (NF), introduced forest (R), forest impacted-by-fire (RF) and native grass pasture with Araucaria trees submitted to an intense accidental fire in September 2004 (NPF). Campos do Jordão, SP, Brazil.

\begin{tabular}{|c|c|c|c|c|c|c|c|}
\hline Area & $\begin{array}{c}\mathrm{pH} \mathrm{CaCl} \\
\left(0.01 \mathrm{~mol} \mathrm{~L}^{-1}\right)\end{array}$ & $\mathrm{OM}^{1}$ & $\mathrm{P}($ resin) & $\mathrm{K}$ & $\mathrm{Ca}$ & $\mathrm{Mg}$ & $\mathrm{H}+\mathrm{Al}$ \\
\hline & & $\mathrm{g} \mathrm{dm}^{-3}$ & $\mathrm{mg} \mathrm{dm} \mathrm{d}^{-3}$ & \multicolumn{4}{|c|}{ mmol $\mathrm{dm}^{-3}$} \\
\hline NF & 3.7 & 158.4 & 9.8 & 3.4 & 3.0 & 2.3 & 209.1 \\
\hline $\mathrm{R}$ & 3.9 & 139.7 & 3.9 & 2.2 & 1.5 & 1.0 & 175.7 \\
\hline $\mathrm{RF}$ & 3.9 & 160.3 & 8.4 & 3.0 & 2.3 & 1.5 & 198.0 \\
\hline NPF & 3.9 & 42.4 & 3.5 & 3.1 & 2.0 & 1.5 & 96.0 \\
\hline
\end{tabular}

${ }^{1} \mathrm{OM}=$ organic matter (Walkey-Black Method). 
$\mathrm{S}$ and $45^{\circ} 27^{\prime} 52^{\prime \prime} \mathrm{W}$, with a mean elevation of 1,467 $\mathrm{m})$, with predominance of Araucaria trees, and low anthropogenic interference (NF); a reforested Araucaria plot $\left(22^{\circ} 39^{\prime} 31^{\prime \prime} \mathrm{S}\right.$ and $45^{\circ} 26^{\prime} 34^{\prime \prime} \mathrm{W}$, with a mean elevation of 1,559 m), planted in $1959(\mathrm{R})$; a reforested Araucaria plot planted in 1959 (22 $39^{\circ} 49^{\prime \prime} \mathrm{S}$ and $45^{\circ} 26^{\prime} 58^{\prime \prime} \mathrm{W}$, with a mean elevation of $1,549 \mathrm{~m}$ ), affected by intense accidental fire in July 2001 (RF); and a natural pasture area containing native Araucaria trees $\left(22^{\circ} 40^{\prime} 38^{\prime \prime} \mathrm{S}\right.$ and $45^{\circ} 28^{\prime} 18^{\prime \prime} \mathrm{W}$, with a mean elevation of $1,501 \mathrm{~m}$ ), affected by intense accidental fire in September 2004 (NPF). Due to the high variability of the areas and the very little knowledge on the diversity of the present soil spider families, the sampling area in each forest was reduced to approximately 0.3 ha, in order to control some critical site characteristics and avoid confounding effects.

NF consists of Araucaria angustifolia and other shrubby, herbaceous and arboreal species, belonging to the families Aquifoliaceae, Araucariaceae, Asteraceae, Cyatheaceae, Lauraceae, Myrsinaceae, Myrtaceae, Podocarpaceae, Rhamnaceae, Rosaceae, Simaroubaceae, Solanaceae, Symplocaceae, Vochysiaceae, and Winteraceae. Area R has several Podocarpus lambertii Klotz trees (Podocarpaceae), but with a predominance of the same Araucaria species as in the NF area. Due to fire, the RF area has a smaller Araucaria density (same species as in $\mathrm{R}$ and NF) and a predominance of Aristida longiseta (grass) and Braccharis trimera (Compositae). Additional information on the arboreal, shrubby, and herbaceous flora of the Parque Estadual de Campos do Jordão can be obtained in Robim et al. (1990).

The samples used to evaluate soil chemical characteristics (Table 1) consisted of three subsamples, collected around each randomly selected Araucaria tree, from a soil layer of $0-0.2 \mathrm{~m}$ in the North-N $\left(0^{\circ}\right)$, Eastsoutheast-ESE $\left(112.5^{\circ}\right)$, and West-southwest-WSW $\left(247.5^{\circ}\right)$ directions, which were analyzed according to the methodology described by Raij et al. (2001).

Soil spider samplings were performed in September 2004 (dry period), February 2005 (rainy period), and August 2005 (dry period). For each selected area, ten Araucaria trees were randomly selected and sampling points were taken around each selected Araucaria tree. Distances between sampling points were never greater than $15 \mathrm{~m}$ or smaller than $5 \mathrm{~m}$. Sampling points did not cover the entire Araucaria forest areas and this was taken into account in the interpretation of our results. Two sampling methods were employed: Soil Monolith $(25 \times 25 \mathrm{~cm})$, from the $0-0.3 \mathrm{~m}$ layer (Anderson \& Ingram, 1993); and Pitfall traps method, consisting of glass cylinders measuring $6 \mathrm{~cm}$ in diameter and $12.5 \mathrm{~cm}$ in height, buried in the soil until their open tip was leveled at the soil surface, and maintained for three days in the field (Bachelier, 1963). Two hundred $\mathrm{mL}$ of liquid detergent $(2.5 \%)$ were added to the traps (Baretta et al., 2003). These collection methods (Monolith and Pitfall traps) have already been discussed in spider ecology (Barreiros et al., 2005; Brennan et al., 2005; Rico-G. et al., 2005; Rodrigues, 2005) and soil fauna studies (Baretta et al., 2003).

For the Monolith method $(25 \times 25 \mathrm{~cm})$, the sample (litter + soil) was screened manually to separate soil and plant fragments from the spiders. The samples from Pitfall traps were successively passed through three sieves of different mesh size; 0.2, 0.15, and $0.1 \mathrm{~mm}$, respectively. Residuals were then stored in flasks containing a 70\% ethyl alcohol solution. In the laboratory, the spiders were separated and identified by specific literature (Brescovit et al., 2002; Platnick, 2006). Because species identification is based on the presence of the genitalia, which is developed only in adults, this study was performed at the family level, in order to utilize the maximum possible number of individuals. After identification, individuals were labeled, and preserved in $80 \%$ ethyl alcohol. All of the material is deposited in the Arachnid and Myriapod Collection of Instituto Butantan's Arthropod Laboratory (A.D. Brescovit, curator).

Spider family diversity was expressed by the Shannon diversity index $(\mathrm{H}),\left[\mathrm{H}=-\sum\right.$ (pi log pi), where: $\mathrm{pi}=\mathrm{ni} / \mathrm{N} ; \mathrm{ni}=$ density of each family, $\mathrm{N}=$ total number of families], and by family richness, according to Odum (1983). Spider family abundance (spider families per $\mathrm{m}^{-2}$ or per trap $\left.{ }^{-1}\right)$, Shannon diversity index $(\mathrm{H})$, and family richness in the different ecosystems were submitted to the analysis of variance (ANOVA), using the SAS version 6.2 statistical program (SAS Institute, 1996), and mean values were compared by the LSD test $(P<0.05)$. Total abundance of families in the three collections (excluding the collection season effect) was used during the statistical analysis in order to standardize the data and better utilize the information on abundance of individuals.

Spider family abundance was used to obtain the gradient length (DCA). Because this length was larger than three (nonlinear response), we chose to use the correspondence analysis (CA), with the CANOCO version 4.0 software program (Ter Braak, 1986; Ter Braak \& Smilauer, 1998). The relationship between spider family distribution and the four Araucaria ecosystems was determined by means of an ordination created by CA. This ordination method is summarized on a graph (Figure 1) containing perpendicular axes representing the multidimensional variation of a set of response variables (spider families) in the different areas (Ter Braak, 1986; Lawes et al., 2005). 

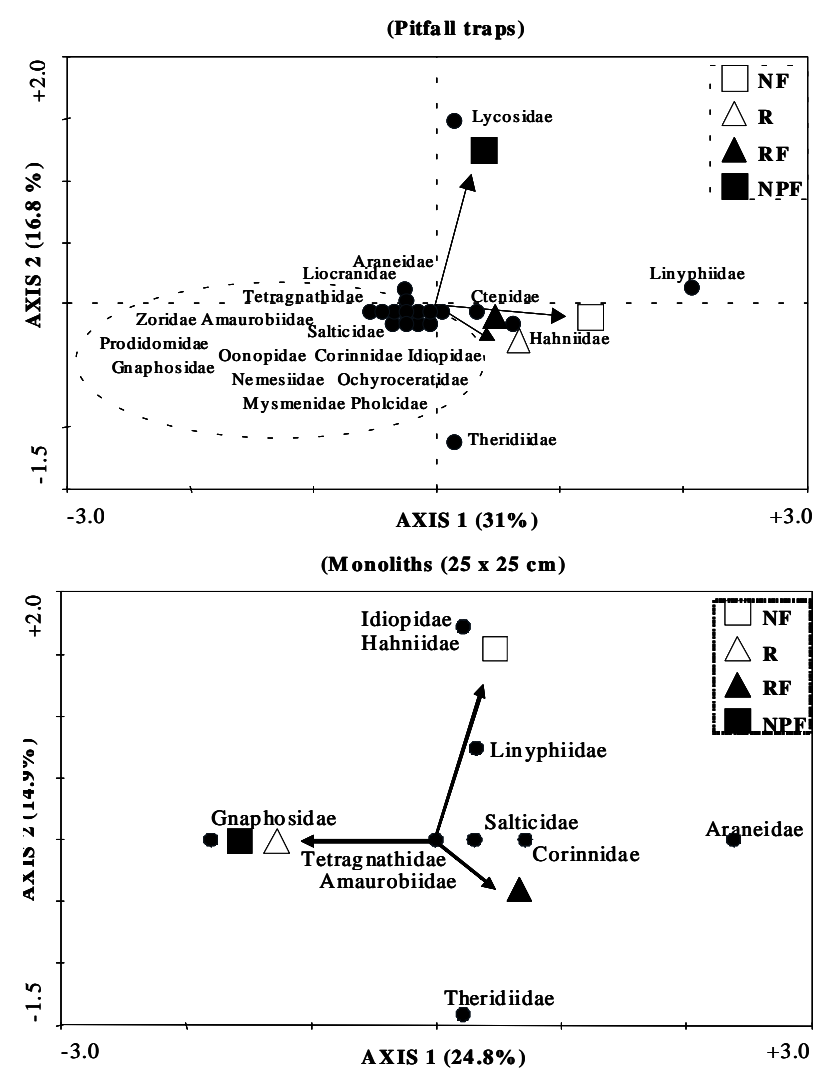

Figure 1 - Relation between axis 1 and 2 of the correspondence analysis (CA), discriminating natural forest (NF: $\square$ ), introduced forest $(\mathrm{R}: \triangle)$, forest impacted-by-fire (RF: A) and native grass pasture with native Araucaria trees submitted to an intense accidental fire (NPF: $\square$ ) and spider families, collected by the "Pitfall trap" and Monolith $(25 \times 25 \mathrm{~cm}$ to a depth of 0-30 cm $)$ methods. Campos do Jordão, SP, Brazil. Mean of ten replicates and three collections $(\mathrm{n}=10 \times 3)$.

\section{RESULTS AND DISCUSSION}

\section{Abundance of spider families}

The presence or absence of different spider families in the four Araucaria forest areas, obtained by the Pitfall trap and Monolith methods (Tables 2 and 3 ) indicate that spider abundance ( specimens trap $^{-1}$ ) in the traps presented a higher total number of specimens in R (65) and NF (41), and a smaller number in NPF (23) and RF (19), perhaps a result of the disturbance to which the sites were subjected (Table 2). The observed trend of a decreasing number of specimens during the study period in NPF and RF cannot be explained by fire alone, but this a typical trend in annual community dynamics linked to the life history of Araucaria areas. The bulk of spider families re-establishing the community and colonizing the burned ecosystems (RF and NPF) probably originated from two main groups: spiders that survived the fire and spiders that emigrated from the surrounding areas. Following a fire there is an immediate decline in spider abundance and taxa richness, at family and species levels, and ecosystem recovery takes less than three years (Brennan et al., 2006), therefore being fast. However, the findings in this study can only be related to active ground dwelling spider families and the results were interpreted under this point of view.

For Pitfall traps, considering the four Araucaria areas, a total of 148 individuals was collected. Furthermore, the Pitfall trap method was more effective, as it captured 19 out of the 20 recorded families, while the Monolith method only extracted ten of those spider families (Tables 2 and 3). The native Araucaria forest (NF), Araucaria reforestation area (R), and Araucaria reforestation area affected by an accidental fire in July 2001 (RF) did not show differences $(P>0.05)$ in spider family richness, with nine, 11, and ten families, respectively (Table 2). A lower number of spider families ( 5 families) was found in the ecosystem submitted to accidental fire in September 2004 (NPF); this area was considered disturbed, particularly because it could not maintain the spider families at the levels observed in the NF (Table 2). Besides, this is an open area with a small number of trees that could present differences in solar exposition, microclimate, and other attributes. This study was dedicated, at least formally, exclusively to ground spiders (Rinaldi \& Forti, 1996).

A similar tendency was found for the Shannon diversity index $(\mathrm{H})$, which were higher in $\mathrm{R}(0.75)$, RF (0.67), and NF (0.63), with no differences among these three forests (Table 2), and were lower in NPF (0.26). The index $\mathrm{H}$ has been frequently reported as an indicator of differentiation between ecosystems (Odum, 1983). However, a problem of interpretation may arise, since diversity, in some circumstances, may increase following moderate habitat disturbance (Petraitis et al., 1989; Scott et al., 2006). In the present study, the effect of the opportunistic families invading the burned areas (RF e NPF) from the open habitats was minimal.

The similarity in the richness of spider families found in those forests (NF, R, and RF) could be related to the fact that sampling was made around Araucaria trees (Table 2), excluding, in part, the effects of plant diversity and ecological trails within the park. However, no similarity in spider family richness had been expected, because native forests in general possess greater habitat heterogeneity and are capable of supporting a greater diversity of edaphic organisms (Lawes et al., 2005).

Although the ten families Ctenidae, Liocranidae, Lycosidae, Mysmenidae, Nemesiidae, Ochyroceratidae, Oonopidae, Pholcidae, Prodidomidae 
Table 2 - Abundance of spider families (specimens traps ${ }^{-1}$ ) collected by the "Pitfall trap" method, discriminating natural forest (NF), introduced forest (R), forest impacted-by-fire (RF) and native grass pasture with native Araucarias trees submitted to an intense accidental fire in September 2004 (NPF). Campos do Jordão, SP, Brazil. Total of ten replicates and three collections $(n=10 \times 3)$.

\begin{tabular}{|c|c|c|c|c|}
\hline Spider family & NF & $\mathrm{R}$ & $\mathrm{RF}$ & NPF \\
\hline Amaurobiidae & $-(1)$ & 2 & - & - \\
\hline Araneidae & 2 & 1 & 2 & - \\
\hline Ctenidae & 4 & 2 & 1 & - \\
\hline Corinnidae & 2 & 1 & 1 & - \\
\hline Gnaphosidae & - & - & - & - \\
\hline Apopyllus sp. & - & - & 1 & - \\
\hline Camillina sp. & - & - & 1 & - \\
\hline Hahniidae & 5 & 5 & - & - \\
\hline Liocranidae & - & - & - & 1 \\
\hline Linyphiidae & 8 & 4 & 3 & 1 \\
\hline Dubiaranea sp. & 5 & - & - & - \\
\hline Erigone sp. & - & - & - & 3 \\
\hline Linyphiidae sp. 1 & 2 & - & - & - \\
\hline Linyphiidae sp. 2 & - & 1 & 1 & 1 \\
\hline Linyphiidae sp. 3 & 5 & 3 & - & - \\
\hline Linyphiidae sp. 4 & 3 & - & - & 1 \\
\hline Linyphiidae sp. 6 & - & - & - & 1 \\
\hline Sphecozone sp. & 1 & 17 & - & - \\
\hline Lycosidae & - & - & 3 & 11 \\
\hline Lycosidae sp. 2 & - & - & - & 1 \\
\hline Mysmenidae & - & - & - & 2 \\
\hline Nemesiidae & - & 1 & - & - \\
\hline Nemesiidae sp. 1 & - & - & 1 & - \\
\hline Nemesiidae sp. 2 & - & 1 & - & - \\
\hline Ochyroceratidae & - & 2 & - & - \\
\hline Ochyrocera sp. & - & 1 & - & - \\
\hline Oonopidae & - & - & 1 & - \\
\hline Pholcidae & - & 1 & - & - \\
\hline Mesabolivar sp. & - & - & 1 & - \\
\hline Prodidomidae & - & - & - & - \\
\hline Lygromma sp. & 1 & - & - & - \\
\hline Salticidae & - & - & - & 1 \\
\hline The ridiidae & 1 & 3 & 1 & - \\
\hline Chrysso sp. & - & 17 & - & - \\
\hline Dipoenura pumicata (Keyserling, 1886) & - & - & 1 & - \\
\hline Guaraniella sp. & - & - & 1 & - \\
\hline Tetragnathidae & 1 & - & - & - \\
\hline Zoridae & 1 & 3 & - & - \\
\hline Total number of specimens trap ${ }^{-1}($ Error Square $= \pm 26.7)$ & $41 \mathrm{ab}$ & 65 a & $19 \mathrm{~b}$ & $23 \mathrm{~b}$ \\
\hline Total families richness (Error Mean Square $= \pm 2.2$ ) & 9 a & $11 \mathrm{a}$ & $10 \mathrm{a}$ & $5 \mathrm{~b}$ \\
\hline Shannon's diversity index (Error Mean Square $= \pm 0.23)$ & $0.63 \mathrm{a}$ & $0.75 \mathrm{a}$ & $0.67 \mathrm{a}$ & $0.26 \mathrm{~b}$ \\
\hline
\end{tabular}

${ }^{(1)}$ Absence of specimens. Means followed by the same letter in the line do not differ $(P<0.05)$ by the LSD test. 
Table 3 - Abundance of spider families (specimens $\left.\mathrm{m}^{-2}\right)$ collected by the Monolith method $(25 \times 25 \mathrm{~cm}$ to a depth of 0-30 $\mathrm{cm})$, discriminating natural forest (NF), introduced forest (R), forest impacted-by-fire (RF) and native grass pasture with native Araucaria trees submitted to an intense accidental fire in September 2004 (NPF). Campos do Jordão, SP, Brazil. Total of ten replicates and three collections $(n=10 \times 3)$.

\begin{tabular}{|c|c|c|c|c|}
\hline Spider family & $\mathrm{NF}$ & $\mathrm{R}$ & $\mathrm{RF}$ & NPF \\
\hline Amaurobiidae & $-(1)$ & - & - & - \\
\hline Amaurobiidae sp. 1 & 16 & - & - & - \\
\hline Amaurobiidae sp. 2 & - & 32 & - & - \\
\hline Araneidae & - & - & 16 & - \\
\hline Corinnidae & 16 & - & 16 & - \\
\hline Gnaphosidae & - & - & - & 16 \\
\hline Hahniidae & 16 & - & - & - \\
\hline Idiopidae & - & - & - & - \\
\hline Idiops sp. & 16 & - & - & - \\
\hline Linyphiidae & - & - & - & - \\
\hline Linyphiidae sp. 1 & 32 & - & 16 & - \\
\hline Tetragnathidae & - & - & - & - \\
\hline Diphya sp. & 16 & - & - & - \\
\hline The ridiidae & - & - & 16 & - \\
\hline Theridion sp. & - & - & 16 & - \\
\hline Dipoena sp. & - & - & 16 & - \\
\hline Steatoda sp. & 16 & - & - & - \\
\hline Salticidae & 32 & - & - & - \\
\hline Total number of specimens $\mathrm{m}^{-2}($ Error Square $= \pm 22.9)$ & $160 \mathrm{a}$ & $32 \mathrm{~b}$ & $96 \mathrm{ab}$ & $16 \mathrm{~b}$ \\
\hline Total families richness (Error Mean Square $= \pm 1.5$ ) & 8 a & $1 \mathrm{c}$ & $4 \mathrm{~b}$ & $1 \mathrm{c}$ \\
\hline Shannon's diversity index (Error Mean Square $= \pm 0.1$ ) & $0.35 \mathrm{a}$ & $0.10 \mathrm{c}$ & $0.27 \mathrm{~b}$ & $0.10 \mathrm{c}$ \\
\hline
\end{tabular}

${ }^{(1)}$ Absence of specimens. Means followed by the same letter in the line do not differ $(P<0.05)$ by the LSD test.

and Zoridae were not captured by the Monolith method, they still must be considered true inhabitants of the Araucaria forest areas. In this case, the absence of some spider species may be more associated with the effectiveness of the sampling method than with the actual abundance of the group (Barreiros et al., 2005). With regard to this fact, a number of other examples could be pointed out in the same tables showing the presence or absence of certain spider families (Tables 2 and 3) in the different Araucaria forest areas.

For the Monolith method, considering the four Araucaria areas, a total of 304 specimens was collected (Table 3). These numbers are much higher than those obtained by Rodrigues (2005), who recorded 130 specimens on average in a shoal forest in the State of Rio Grande do Sul, Brazil.

The NF ecosystem presented the highest family richness ( 8 families), followed by RF, R, and NPF (4, 1 , and 1 families, respectively); no significant differences of family richness were found between $\mathrm{R}$ and NPF (Table 3). Rico-G. et al. (2005) studied different spider collection methods in a Natural National Park in Colombia, and demonstrated that a manual collec- tion method was more effective than two other methods, as it extracted 33 of the recorded 34 families, with family Gnaphosidae only being extracted by manual collection.

A similar tendency for family richness was also found for $\mathrm{H}$, highest in NF (0.35), followed by RF (0.27), R (0.10), and NPF (0.10), respectively (Table 3). The last two areas (R and NPF) did not differ from each other. However, in the case of spider families, $\mathrm{H}$ can change rapidly from season to season, particularly during the mating (more active) periods of the abundant families which may produce sharp peaks in recorded numbers (Scott et al., 2006).

The Monolith method yielded higher total numbers of specimens $\mathrm{m}^{-2}$ in NF (160) and RF (96), and smaller numbers in R (32) and NPF (16) (Table 3). Some authors suggest that the diversity in vegetation cover may also influence the composition and richness of spider communities (Rushton et al., 1987; Lawes et al., 2005; Warui et al., 2005). Variables potentially influencing family and species richness are litter, depth, bare ground, densities of dead and of living vegetation (Brennan et al., 2006). 
Abbott et al. (2003) reported minimal change in spider species composition in assemblage structure from logging and burning when compared to controls. Others studies showed that enclosure treatments affected plant cover, with the presence of cattle significantly reducing the relative vegetation cover and spider diversity of a Kenyan savanna biome. In this study, the presence or absence of spider families were found to be an indicator of the anthropogenic disturbance and could be used for bio-monitoring, as indicators of land use changes (Warui et al., 2005). Therefore, the type of employed sampling method influences the results for spider family richness (Tables 2 and 3), as well as edaphic fauna abundance and diversity (Baretta et al., 2003; Barreiros et al., 2005). However, experimental results involving family surveys in which a single sampling method was used point towards the poor reliability they deserve. For a higher reliability in biodiversity studies on families associated to peculiar forest ecosystems, it is suggested that more than one sampling method must be used to evaluate the presence or absence of edaphic spider families.

\section{Correspondence analysis (CA)}

For the Pitfall traps, for example, axis 1 and axis 2 corresponded to $31 \%$ and $16.8 \%$ of total inertia, respectively (Therefore, Axis 1 matters much more than Axis 2), explaining together about $50 \%$ of total data variability (Figure 1). Along dimension 1 (main axis), NPF is displayed on the farthest right portion of the graph (with positive values), while NF, R and $\mathrm{RF}$ are shown on the middle right portion (but with negative values), indicating a clear separation among the different stands. This analysis also allows us to visualize a greater or smaller association of each spider family with each Araucaria forest area, by the proximity between both variables (areas and spider family), i.e., the nearer the variables, the more frequent their occurrence together. In this respect, family Lycosidae captured by traps showed association with the area submitted to fire (NPF), while families Ctenidae, Hahniidae, and Theridiidae showed greater association with the other forests (NF, R, and RF). The other families captured by the traps (Araneidae, Liocranidae, Tetragnathidae, Zoridae, Amaurobiidae, Salticidae, Prodidomidae, Oonopidae, Corinnidae, Idiopidae, Gnaphosidae, Nemesiidae, Ochyroceratidae, Mysmenidae, Pholcidae) were not specifically associated to any of the Araucaria forests and contributed very little to total inertia, since they are located in the middle portion of figure 1 .

For the Monolith method $(25 \times 25 \mathrm{~cm})$ a separation was observed among areas, by means of the relation between axes 1 and 2, with the exception of $R$ and NPF, which were very close to each other (Figure 1). On the other hand, when the areas occur in separate quadrants, this indicates that the spider family abundance occurred differently in those environments. Nevertheless, the Monolith method $(25 \times 25$ $\mathrm{cm}$ ) was not as effective as the Pitfall trap method in discriminating areas, since axis 1 explained $24.8 \%$ of data variability found in the four Araucaria forest areas, while axis 2 explained only $14.9 \%$ of that variation. These values are smaller than those obtained with the Pitfall trap method (Figure 1). The lower effectiveness of the Monolith method in separating areas could be explained by it's ineffectiveness in extracting spider families, as previously discussed (Tables 2 and 3). Therefore, standardization and calibration of sampling methods and protocols are fundamental issues for the comparison of sites and definition of priority areas for conservation.

Along dimension 1 (main axis) for the Monolith method (Figure 1), NF is displayed on the far right portion of the graph, with positive values, while RF is shown on the right, with negative values; R and NPF, however, were very close to each another, arranged on the middle portion to the left, demonstrating a high similarity between these Araucaria forest areas. Families Idiopidae (only extracted by this method), Hahniidae, Salticidae, Linyphiidae, and Corinnidae showed greater association with NF. However, families Corinnidae, Araneidae, and Theridiidae were associated with the forest submitted to fire in 2001 (RF). Family Gnaphosidae showed greater association with NPF (Figure 1), which confirms the presence of this single family as soon as 11 months after the occurrence of accidental fire in this area (Table 3). Families Tetragnathidae and Amaurobiidae, in turn, did not show a strong association with any of the Araucaria forest areas. However, the greater or smaller association of a given soil spider family in each forest varies both spatially and temporally. The greater or smaller association of a given soil spider family with each area, in general, is mainly due to the beneficial effect of plant residues and litter diversity kept on the soil surface, which provided a favorable environment for the survival or establishment of edaphic invertebrates (Lawes et al., 2005).

In the present study, the effectiveness of collection methods and manner by which spider families (ecological data) are analyzed statistically must be taken into consideration if actual functional changes caused by anthropogenic pressures on Araucaria forest are to be predicted with higher reliability. The CA indicates that the presence or absence of a given soil spider family could have been influenced by stress situations, such as, for example, anthropogenic per- 
turbations, and other attributes. Thus, it is here attempted to make a contribution to the scientific knowledge on the impacts of anthropogenic pressure in soil spider families, aiming at preserving forests containing native Araucaria trees and the adoption of reforestation programs or restoration attempts (see also Oxford \& Scott, 2003), in order to sustain the soil spider families.

In conclusion, the presence or absence of spider families and their abundances were sensitive ecological indicators of human intervention in forests of Araucaria trees at the Parque Estadual de Campos do Jordão, SP. Thus, in Araucaria forest areas influenced or not by anthropogenic action, where resources are limited, identification to the family level may be an effective procedure, allowing the incorporation of spiders into broader studies designed to evaluate a given Araucaria forest as well as providing an indication of soil quality. The obvious advantage of sorting spiders at the family level, as opposed to species level is that in areas where the spider fauna is poorly known taxonomically, identification will be easier and hence faster. Some caution must be warranted in the interpretation of the results presented here, because they refer only to families that were active during the study period (Brennan et al., 2006). The numerical relationships found in this study also need to be tested outside the present study area. Nevertheless, we suggest, that changes in the abundance and diversity of soil spider families in Araucaria forest are mainly due to recurrent human intervention over the last few years.

\section{ACKNOWLEDGMENTS}

D. Baretta, A.D. Brescovit and E.J.B.N. Cardoso thank CNPq for fellowships granted to them. The authors thank the BIOTA/FAPESP program for funding the project (No. 01/05146-6 and ADB, 99/ 05446-8), IBAMA for the required collection permit (No. 02027.002353/05-94) and Instituto Butantan (SP). Thanks also go to Campos do Jordão State Park employees for their assistance during collections, as well as to ESALQ/USP technicians Denise Mescolotti, Dorival Grisotto, and Luis F. Baldesin, and graduate students Mauricio V. Alves (CAV/UDESC) and André L. Monfrinato (UNIMEP) for their help. We are grateful to Dr. Matthieu Chauvat (ECODIV/University of Rouen, France) and Cristina Seabra Ferreira (University of Coimbra, Portugal) for suggestions on a first version of this manuscript, which is part of BIOTA/ FAPESP - The Biodiversity Virtual Institute Program (www.biotasp.org.br). Comments from three anonymous referees improved the clarity of the paper.

\section{REFERENCES}

ABBOTT, I.; BURBIDGE, T.; STREHLOW, K.; MELLICAN, A.; WILLS, A. Logging and burning impacts on cockroaches, crickets and grasshoppers, and spiders in Jarrah forest, Western Australia. Forest Ecology and Management, v.174, p.383$399,2003$.

ANDERSON, J.M.; INGRAM, J.S.I. Tropical soil biology and fertility: a handbook of methods. 2.ed. Wallingford: $C A B$ International, 1993. 171p.

BACHELIER, G. La vie animale dans les sols. Paris: Orstsom, 1963. 279p.

BARETTA, D.; SANTOS, J.C.P.; MAFRA, Á.L.; WILDNER, L. do P.; MIQUELLUTI, D.J. Fauna edáfica avaliada por armadilhas e catação manual afetada pelo manejo do solo na região oeste catarinense. Revista de Ciências Agroveterinárias, v.2, p.97106, 2003.

BARREIROS, J.A.P.; PINTO-DA-ROCHA, R.; BONALDO, A.B. Abundância e fenologia de Cryptocellus simonis Hansen \& Sørensen, 1904 (Ricinulei, Arachnida) na serapilheira do Bosque Rodrigues Alves, Belém, Pará, Brasil, com a comparação de três técnicas de coleta. Biota Neotropica, v.5, p.69-77, 2005.

BENATI, K.R.; SOUZA-ALVES, J.P.; SILVA, E.A.; PERES, M.C.L.; COUTINHO, É.O. Aspectos comparativos das comunidades de aranhas (Araneae) em dois remanescentes de Mata Atlântica do Estado da Bahia, Brasil. Biota Neotropica, v.5, p.79-87, 2005.

BRENNAN, K.E.C.; MAJER, J.D.; MOIR, M.L. Refining sampling protocols for inventorying invertebrate biodiversity: influence of drift-fence length and Pitfall trap diameter on spiders. The Journal of Arachnology, v.33, p.681-702, 2005.

BRENNAN, K.E.C.; ASHBY, L.; MAJER, J.D.; MOIR, M.L.; $\mathrm{KOCH}$, J.M. Simplifying assessment of forest management practices for invertebrates: How effective are higher taxon and habitat surrogates for spiders following prescribed burning? Forest Ecology and Management, v.231, p.138-154, 2006.

BRESCOVIT, A.D. Araneae. In: BRANDÃO, C.R.F.; VASCONCELOS, E.M. Biodiversidade do Estado de São Paulo, Brasil: Síntese do conhecimento ao final do século XX. São Paulo: FAPESP, 1999. p.45-56.

BRESCOVIT, A.D.; BONALDO, A.B.; BERTANI, R.; RHEIMS, C.A. Araneae. In: ADIS, J. (Org.) Amazonian Arachnida and Myriapoda. Identification keys to all classes, orders, families, some genera, and lists of known terrestrial species. Moscow: Pensoft Publisher, 2002. p.303-343.

CANDIANI, D.F.; INDICATTI, R.P.; BRESCOVIT, A.D. Composição de diversidade da araneofauna (Araneae) de serapilheira em três ecossistema urbanas na cidade de São Paulo, São Paulo, Brasil. Biota Neotropica, v.5, p.111-123, 2005.

HARRIS, I.D. The fragmented forest: island biogeography theory and the preservation of biotic diversity. Chicago: University of Chicago Press, 1984. 229p.

INDICATTI, R.P.; CANDIANI, D.F.; BRESCOVIT, A.D.; JAPYASSÚ, H.F. Diversidade de aranhas (Arachnida, Araneae) de solo na Bacia do Reservatório do Guarapiranga, São Paulo, São Paulo, Brasil. Biota Neotropica, v.5, p.151-162, 2005.

KEYSERLING, E. Die Spinnen Amerikas. Theridiidae, v.2, p.1295, 1886

LAWES, M.J.; KOTZE, D.J.; BOURQUIN, S.L. Epigeic invertebrates as Potential Ecological Indicators of Afromontane Forest Condition in South Africa. Biotropica, v.37, p.109$118,2005$.

MOREIRA, M.; BARETTA, D.; TSAI, S.M.; CARDOSO, E.J.B.N. Spore density and root colonization by arbuscular fungi in preserved or disturbed Araucaria angustifolia (Bert.) O. Ktze. ecosystems. Scientia Agricola, v.63, p.380-385, 2006.

ODUM, E.P. Ecologia. Rio de Janeiro: Guanabara, 1983. 434p.

OXFORD, G.S.; SCOTT, A.G. The spider fauna of Askham Bog, York, and the assessment of conservation value. Naturalist, v.128, p.157-170, 2003. 
PETRAITIS, P.S.; LATHAM, R.E.; NIESENBAUM, R.A. The maintenance of species diversity by disturbance. Quarterly Review of Biology, v.64, p.393-418, 1989.

PINKUS-RENDÓN, M.A.; LEÓN-CORTÉS, J.L.; IBARRANÚNEZ, G. Spider diversity in tropical habitat gradient in Chiapas. Mexico. Diversity and Distributions, v.12, p.6169, 2006

PLATNICK, N.I. The world spider catalog, version 7.0. New York: American Museum of Natural History, 2006. Available at: http://research.amnh.org/entomology/spiders/catalog/ index.html. Accessed at: July, 13, 2006.

RAIJ, B.; QUAGGIO, J.A.; CANTARELlA, H.; ANDRADE, J.C. Análise química para avaliação da fertilidade de solos tropicais. Campinas: Instituto Agronômico, 2001. 284p.

RICO-G., A.; BELTRÁN, J.P.A.; ÁLVAREZ, A.D.; FLÓREZ, E.D. Diversidad de arañas (Arachnida: Araneae) en el Parque Nacional Natural Isla Gorgona, Pacífico Colombiano. Biota Neotropica, v.5, p.99-110, 2005.

RINALDI, I.M.P.; FORTI, L.C. Strategies for habitat use among species of hunting spiders (Araneomorphae, Dionycha) in natural and artificial biotopes from southeastern Brazil. Acta Biologica Paranaense, v.25, p.115-139, 1996.

ROBIM, M.de.J.; PASTORE, J.A.; AGUIAR, O.T.de.; BAITELLO, J.B. Flora arbóreo arbustiva e herbácea de Parque Estadual de Campos do Jordão (SP). Revista do Instituto Florestal, v.2, p.31-53, 1990

RODRIGUES, E.N.L. Araneofauna de serapilheira de duas áreas de uma mata de restinga no município de Capão do Leão, Rio Grande do Sul, Brasil. Biotemas, v.18, p.73-92, 2005.
RUSHTON, S.P.; TOPPING, C.J.; EYRE, M.D. The habitat preferences of grassland spiders as identified using detruded correspondence analysis (Decorama). Bulletin of the British Arachnological Society, v.7, p.165-170, 1987.

SAS Institute. SAS/STAT, Release 6.2. Cary: SAS Institute Inc., 1996.

SCOTT, A.G.; OXFORD, G.S.; SELDEN, P.A. Epigeic spiders as ecological Indicators of conservation value for peat bogs. Biological Conservation, v.127, p.420-428, 2006.

TER BRAAK, C.J.F. Canonical correspondence analysis: a new eigenvector technique for multivariate direct gradient analysis. Ecology, v.67, p.1167-1179, 1986.

TER BRAAK, C.J.F.; SMILAUER, P. CANOCO reference manual and user's guide to Canoco for Windows: Software for canonical community ordination (version 4). New York: Microcomputer Power, 1998.

WARUI, C.M.; VILLET, M.H.; YOUNG, T.P.; JOCQUÉ, R. Influence of grazing by large mammals on the spider community of a Kenyan savana biome. Journal of Arachnology, v.33, p.269-279, 2005.

Received September 29, 2006

Accepted April 23, 2007 